\title{
Viral Studies in Streptozotocin-Induced Pancreatic Insulitis
}

\author{
M. C. Appel, A. A. Rossini, R. M. Williams, and A. A. Like \\ Department of Pathology, University of Massachusetts Medical School, Worcester, Massachusetts, \\ and Elliott P. Joslin Research Laboratory and Division of Tumor Immunology, Sidney Farber Cancer Institute, \\ Department of Medicine, Harvard Medical School Boston, Massachusetts, USA
}

Summary. Multiple injections of streptozotocin to Charles River (CD-1) Laboratory mice resulted in a syndrome characterised by diabetes mellitus, insulitis and the induction of endogenous type $C$ viruses in pancreatic beta cells. Within one week after the completion of five intraperitoneal injections of streptozotocin, the CD-1 mice exhibited irreversible hyperglycaemia and insulinopaenia. Light microscopic studies of pancreata from mice sacrificed at this time demonstrated insulitis and beta cell necrosis. Electron microscopic studies revealed spherical and atypical cylindrical type $\mathrm{C}$ viruses and occasional clusters of intracisternal type A viruses exclusively within beta cells. To clarify the identification of the type $C$ viruses and their role in the genesis of the insulitis, type $\mathrm{C}$ virus specific antigens were identified within islet cells by immune fluorescence at various intervals after streptozotocin administration. Immune fluorescence studies demonstrated the presence of type $\mathrm{C}$ virus antigens within islets from streptozotocin treated mice but not in buffer-injected controls. Time course studies suggested that type $\mathrm{C}$ virus induction may precede the appearance of insulitis by two days and that insulitis is consistently accompanied by the presence of virus positive islet cells.

Key words: Diabetes mellitus, streptozotocin, type C leukaemia virus, intracisternal type A virus, insulitis, cell-mediated immunity, insulin.

Considerable interest has been generated in the possible pathogenetic roles of autoimmune disorders and infectious viral agents in the aetiology and progression of diabetes mellitus. The implication of abnor- mal autoimmune mechanisms is based upon the clinical observation that diabetes is frequently associated with autoimmune diseases of the thyroid $[1,2,3]$, adrenal cortex $[4,5]$, haemapoietic tissues $[3,6]$ and gastric mucosa $[3,7]$. In addition, lymphocytic infiltration of the islets of Langerhans [8] and humoral islet-specific antibodies $[9,10]$ in juvenile-onset insulin-dependent diabetes of short duration have been reported. Evidence suggesting a pathogenetic role of viruses in diabetes stems from clinical observations showing a close temporal relationship between the onset of diabetes in children and preceding infections by mumps [11], rubella [12] and coxsackie B-4 viruses [13]. Additional experimental data have also shown that the $\mathbf{M}$ variant of encephalomyocarditis virus destroys pancreatic beta cells in selected mouse strains resulting in insulin-dependent diabetes [14].

Earlier reports from this laboratory $[15,16,17]$ described a model of experimentally induced diabetes which was produced by the administration of multiple subdiabetogenic doses of streptozotocin to Charles River Laboratory mice. Diabetes was characterised by delayed, progressive hyperglycaemia, severe pancreatic insulitis and the induction of endogenous type $\mathrm{C}$ viruses within pancreatic beta cells. Conclusive viral indentification, however, was made difficult by the absence of viral budding from external plasma membranes of virus producing beta cells. Furthermore, the virus induction and the composition and delayed arrival of the inflammatory infiltrate suggested that the type $C$ virus may have played a causal role in the insulitis by the initiation of a cell-mediated immune response.

This report describes experiments designed to identify the observed viruses by immunohistochemical techniques and to describe more comprehensively the ultrastructural events associated with virus induc- 


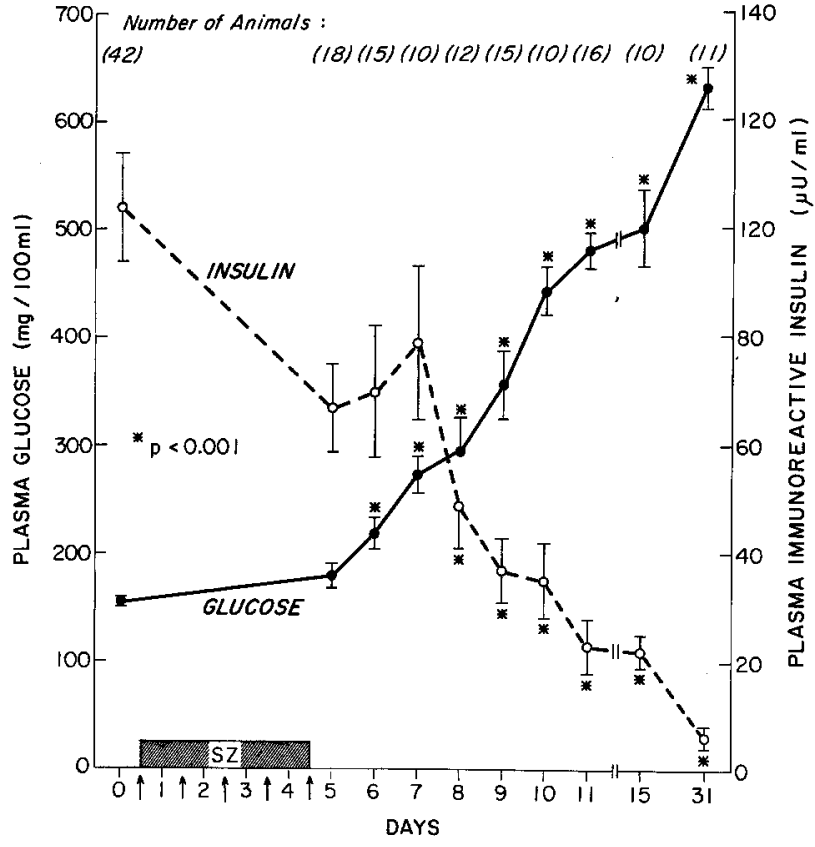

Fig. 1. Plasma glucose and immunoreactive insulin in CD-1 mice following five IP injections of streptozotocin $(40 \mathrm{mg} / \mathrm{kg} /$ day $\times 5$ days). Each data point represents the mean \pm SEM for groups of mice sacrificed on the indicated day

tion. In addition, studies are described which establish the temporal relationship between the onset of virus induction and the arrival of the inflammatory cells.

\section{Materials and Methods}

Male $30-40 \mathrm{~g}$ outbred Charles River Laboratory (CD-1) mice were given five daily intraperitoneal injections of streptozotocin ( $40 \mathrm{mg} / \mathrm{kg}$ ), dissolved in $0.1 \mathrm{~mol} / 1$ citrate buffer ( $\mathrm{pH} 4.2$ ) immediately before injection. Animals of the same weight and sex receiving an equal volume of citrate buffer served as controls. All animals were provided with Old Guilford mouse chow (96W) and water ad libitum. Blood samples were collected between $10: 00-12: 00 \mathrm{AM}$ from the orbital venous sinus and aliquots of plasma were analysed for glucose [18] and immunoreactive insulin [19]. Animals were sacrificed by exsanguination on the fifth through tenth days following the initial streptozotocin injection and the pancreata were excised and prepared for cryotomy or light microscopy.

\section{Immunohistochemistry Procedures}

Identification of murine leukaemia viruses was accomplished using a direct immune fluorescence technique. Acetone fixed cryostat $(8 \mu)$ sections of pancreas were incubated with a solution $(1: 60)$ of goat anti-Moloney leukaemia virus antibody conjugated with fluorescein isothiocyanate (G-AMLV-FITC) and rhodamine counterstain $(1: 5)$ diluted in phosphate buffered saline (PBS). Pancreatic sections were allowed to incubate for $1 \mathrm{~h}$ at $37^{\circ} \mathrm{C}$. The tissues were then rinsed in PBS, mounted using glycerol: PBS
(9:1) and examined with a Zeiss fluorescence microscope equipped for epi-illumination.

\section{Electron Microscopy}

Buffer injected control mice $(n=4)$ and mice treated with streptozotocin on the fifth $(n=4)$ and eleventh $(n=6)$ days following the initial streptozotocin injection were selected for electron microscopic studies. Animals were anaesthetised with Nembutal ${ }^{\circledR}$ sodium solution and perfused via cardiac canulae with Ringer's lactate solution containing $1 \mathrm{U} / \mathrm{ml}$ each of heparin and procaine. Tissues were subsequently fixed by perfusion with a solution of phosphate buffered paraformaldehyde $(0.1 \mathrm{~g} / 1)$ and glutaraldehyde $(0.125 \mathrm{~g} / \mathrm{l})$ containing $\mathrm{CaCl}_{2}(0.555 \mathrm{~g} / \mathrm{l})$, trinitrocresol $(0.2 \mathrm{~g} / 1)$ and $(0.2 \mathrm{~g} / \mathrm{l})$ polyvinylpyrolidone $(\mathrm{pH} 7.4)$. Islets of Langerhans were isolated from the exocrine pancreas by free-hand microdissection and were postfixed with $(0.133 \mathrm{~g} / \mathrm{l})$ phosphate buffered osmium tetroxide. Tissues were then "stained" en-bloc with uranyl acetate $(0.15 \mathrm{~g} / \mathrm{l})$ in $0.05 \mathrm{~mol} / 1$ sodium maleate buffer ( $\mathrm{pH}$ 5.2) and embedded in a mixture of epon-araldite. Sections were stained sequentially with aqueous uranyl acetate and lead citrate [20] and were examined with either a Philips 301 or a JEM 100 S electron microscope.

\section{Miscellaneous}

Stretozotocin was generously supplied by Dr. William E. Dulin (Upjohn Company, Kalamazoo, Michigan). The lot numbers and anomeric composition of streptozotocin were as follows: \#10517 $=\alpha-50 \%, \beta-50 \% ; \# 10518=\alpha-90 \%, \beta-10 \% ; \# 60140$ $=\alpha 88 \% . \beta-12 \% ; \# 118 \mathrm{~F}-1=\alpha-25 \%, \beta-75 \%$. Guinea pig anti-insulin serum used in the insulin radioimmunoassay was obtained from Dr. Peter Wright (Department of Pharmacology, Indiana University, Indianapolis, Indiana). G-AMLV-FITC was kindly supplied by Dr. Roger Wilsnak (Huntington Research Center, Bethesda, Maryland). This antiserum was prepared against Tween-ether disrupted Moloney leukaemia virus and cross reacts with all known strains of murine leukaemia virus [21].

\section{Results}

\section{Plasma Glucose and IRI}

The plasma glucose and immunoreactive insulin (IRI) levels in CD-1 mice after five intraperitoneal injections of stretozotocin are shown in Figure 1. Normal plasma glucose levels were found during the first four days of streptozotocin injections but progressive hyperglycaemia was found thereafter. By the tenth day after the onset of streptozotocin treatment, the mean plasma glucose concentration was $445 \mathrm{mg} /$ $100 \mathrm{ml}$ and remained above this level thereafter. Conversely, mean plasma IRI was significantly reduced from the pre-injection levels by the eight day and was detectable only in trace concentrations after the first month. Spontaneous recovery from hyperglycaemia and hypoinsulinaemia was not observed. 


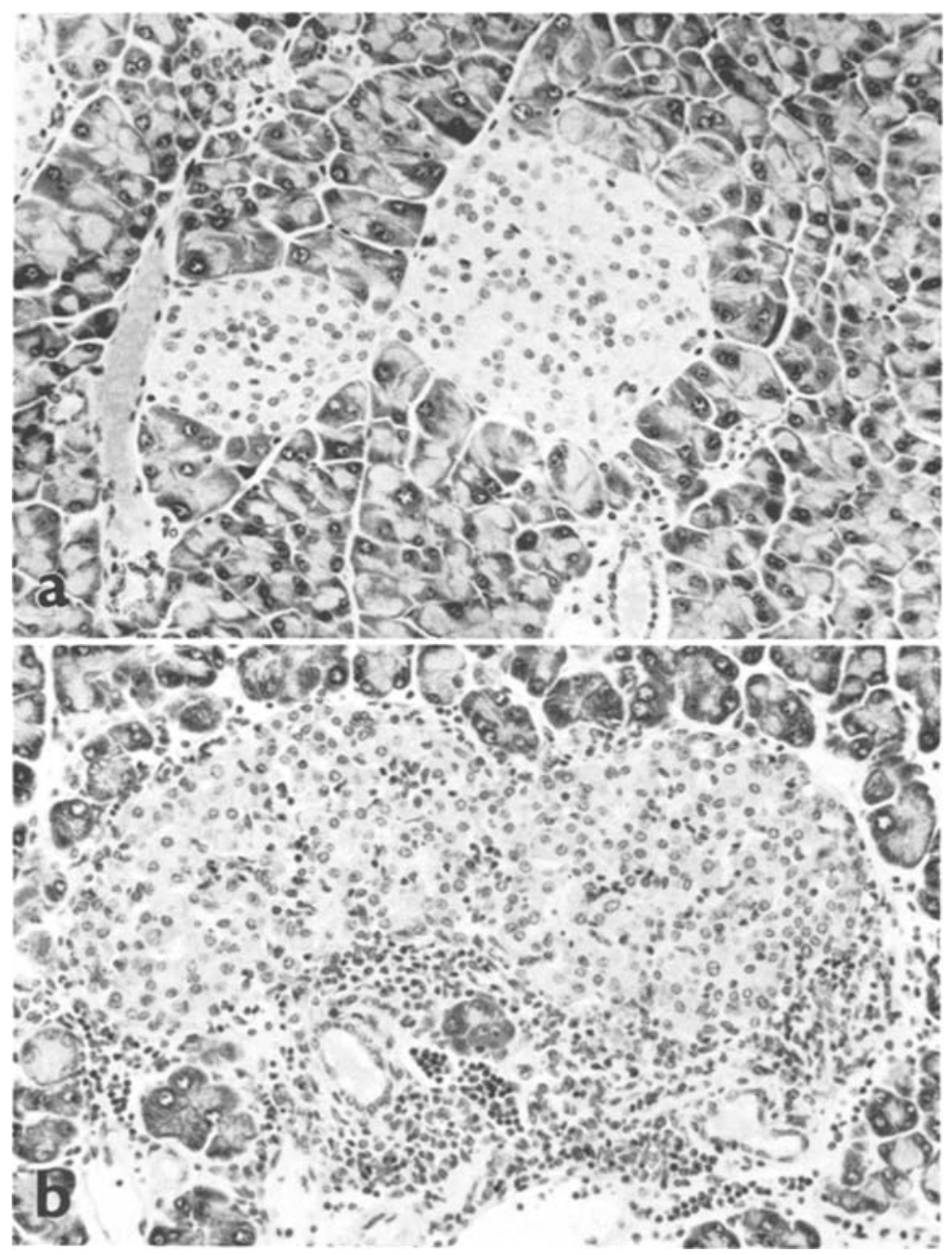

Fig. 2. a Islets from buffer injected CD-1 mouse showing normal morphology. Haematoxylin and eosin. 212 $\times$ magnification. $b$ Islets from $C D-1$ mouse sacrificed six days after completion of five streptozotocin injections demonstrating severe insulitis. Inflammatory cells surround and permeate the islet parenchyma. Cytoarchitecture of component islet cells is disorganised. Haematoxylin and eosin. $212 \times$ magnification

\section{Light Microscopy}

The islets from control CD-1 mice $(n=10)$ were normal morphologically (Fig. 2 A) and showed no evidence of virus specific fluorescence after incubation with G-AMLV-FITC (Fig. 3 A). Foci of fluorescence were intermittently observed in pancreatic acinar cells from control animals. Weak fluorescence was occasionally observed in islet cells from control animals displaying concomitant pancreatic acinar cell fluorescence, but was never comparable to the intensity observed in streptozotocin treated animals.

At eleven days after the first of five injections with streptozotocin, islets of Langerhans exhibited pronounced disorganisation of the component islet cells with severe insulitis (Fig. 2 B). Interstitial aedema and necrotic cell debris were observed and an extensive round cell infiltrate composed predominantly of lymphocytes and macrophages surrounded and permeated the islets. The appearance of type $C$ virus antigens within the islet cells as observed by fluorescence microscopy is illustrated in
Figure 3 B. Type C virus specific fluorescence was granular, of variable intensity and randomly distributed throughout the cytoplasm of the islet cells. Although virus specific fluorescence was consistently observed in all islets with insulitis, the number of fluorescent positive cells within each islet was variable.

To determine the tissue distribution of murine leukaemia virus in animals with islet cell flourescence after streptozotocin treatment, various extrapancreatic tissues were examined for type $\mathrm{C}$ virus antigens (Table 1). Murine leukaemia virus-specific fluorescence was present in bronchial glandular epithelium, renal glomerular basement membranes, spleen and mesenteric lymph nodes. Splenic and mesenteric lymph nodes from control mice also demonstrated weakly positive virus-specific fluorescence; however, all other tissues from control animals were negative. Murine leukaemia virus antigens in lymphoid tissues of normal mice have been reported by other investigators $[22,23]$.

The temporal relationship between the induction 

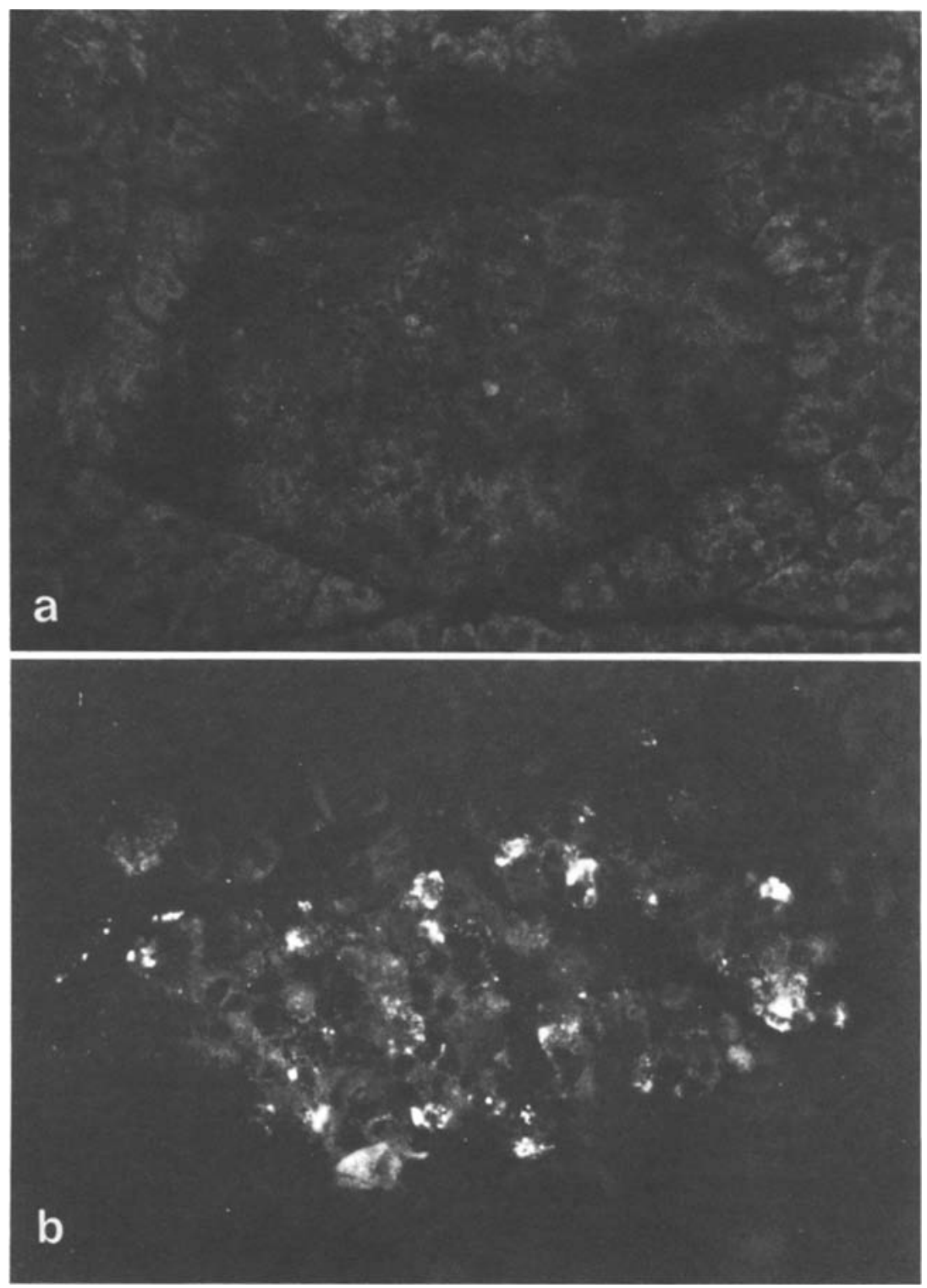

Fig. 3. a Islet from buffer injected CD-1 mouse showing no fluorescence after incubation with G-AMLV-FITC. $525 \times$ magnification. b Islet from streptozotocin treated mouse demonstrating virus specific fluorescence after incubation with G-AMLV-FITC. Fluorescence is granular and is randomly distributed throughout the cytoplasm in islet cells. $525 \times$ magnification of islet type $\mathrm{C}$ viruses and the arrival of inflammatory cells, following streptozotocin treatment, is illustrated in Table 2. Virus-specific antigens were first observed in islets of CD-1 mice on the sixth day following the initial streptozotocin injection and were detected with increasing frequency thereafter. Insulitis was observed on the eighth day and was always associated with virus-specific fluorescence in the pancreatic islets. All animals demonstrated both type $\mathrm{C}$ virus and insulitis by the tenth day.

Several lots of streptozotocin having different alpha-to-beta anomer ratios were tested in CD-1 mice to determine whether these preparations had preferential effects on enhancing viral replication. Variations in the anomeric composition of strep- tozotocin did not appear to produce any consistent effect upon type $\mathrm{C}$ virus induction.

\section{Electron Microscopy}

The component cells from islets of Langerhans of buffer injected control animals exhibited normal ultrastructure (Fig. 4 a). Type $\mathrm{C}$ virus particles were occasionally seen within normal beta cells. The morphology and intracellular location of these particles were similar in beta cells from both control and stretozotocin treated mice.

Type $\mathrm{C}$ viruses were rarely encountered in islets from mice sacrificed on the fifth day of streptozotocin injections. However, beta cells from these islets 
revealed subtle cytoarchitectural abnormalities. Increased interstitial space was observed between component islet cells, suggesting oedema, and the outer surfaces of the beta cells were frequently irregular, forming villus-like projections from membrane surfaces (Fig. 4 b). Morphological abnormalitities were not observed among alpha, delta and pancreatic polypeptide cells after treatment with streptozotocin.

Both spherical and cylindrical type $\mathrm{C}$ virus forms were observed in beta cells from islets of mice sacrificed on the eleventh day after initiation of streptozotocin injections (Figs. $5 \mathrm{a}, 5 \mathrm{~b}$ ). These particles consisted of a spherical core of compact nucleoid having an electron-lucent core centre with a surrounding viral envelope. They were observed budding from the inner surfaces of the rough endoplasmic reticulum cisternae, golgi related vesicles and smooth surfaced cisternae. Budding virus profiles were not observed at the plasma membranes or within interstitial spaces. Virus particles were observed only within islet beta cells and were most commonly seen in those beta cells showing active hormone biosynthesis and secretion - ie: degranulation with increased rough endoplasmic reticulum, enlarged golgi structures and numerous transitional elements. In addition to type $C$ viruses, intracisternal type A particles were occasionally observed within pancreatic beta cells (Figs. 5 a, 5 c). The intracisternal $A$ particles could be differentiated from type $C$ particles by the absence of a viral envelope and the presence of "knob-like" surface projections extending from the outer nucleoid shell. Both intracisternal $A$ and type $C$ virus particles were occasionally observed within the same beta cell.

Wide variation existed in the ultrastructural appearance of beta cells of streptozotocin treated mice sacrificed on the eleventh day. Intact beta cells were observed frequently showing degranulation and enhanced insulin biosynthetic activity as well as necrotic cells in variable degrees of degeneration. Beta cells contained nuclei with irregular contours, increased numbers of lysosomes and frequently contained large numbers of pale secretory granules. Numerous islet associated interstitial and peripheral "activated" lymphocytes were observed as well as macrophages containing beta cell debris (Fig. 6).

\section{Discussion}

The ultrastructural and immunohistochemical studies described above confirm the classification of the virus particles as type $\mathrm{C}$ proposed earlier [15]. The significance of the atypical cylindrical forms, however, remains uncertain. Similar filamentous or cylindrical
Table 1. Tissue distribution of murine leukaemia virus antigens in $\mathrm{CD}-1$ mice sacrificed on the eleventh day after receiving the first of five injections of streptozotocin
Virus positive tissues ${ }^{2}$
Pancreas
Spleen
Mesenteric lymph nodes
Lung (bronchial glandular epithelium)
Kidney (glomerular basement membrane)

Virus negative tissues

Neural tissues

Liver

Heart

Small intestine

Large intestine
Stomach
Salivary gland Adenohypophysis Adrenal cortex

Adrenal medulla

Thyroid

Testis a Observations are based on tissues obtained from a minimum of four mice which demonstrated positive islet virus specific fluorescence

Table 2. Temporal relationship between the presence of islet type $\mathrm{C}$ viruses and insulitis following streptozotocin treatment

\begin{tabular}{|c|c|c|c|c|c|c|}
\hline Days Post-Injection & 5 & 6 & 7 & 8 & 9 & 10 \\
\hline & $0 \%$ & $33 \%$ & $17 \%$ & $75 \%$ & $75 \%$ & 100 \\
\hline $\begin{array}{l}\% \text { Insulitis } \\
\text { (n) }\end{array}$ & $\begin{array}{l}0 \% \\
(6)\end{array}$ & $\begin{array}{l}0 \% \\
(6)\end{array}$ & $\begin{array}{l}0 \% \\
(6)\end{array}$ & $\begin{array}{l}42 \% \\
(12)\end{array}$ & $\begin{array}{l}75 \% \\
(12)\end{array}$ & $\begin{array}{l}100 \% \\
(6)\end{array}$ \\
\hline
\end{tabular}

a Observations were made at daily intervals after completion of five injections of streptozotocin

type $\mathrm{C}$ virus particles have been described in intact cells of mice with virus-induced leukaemia $[24,25]$, and in various cell lines infected with leukaemia virus $[26,27]$. Treatment of cultured hepatoma cells with the mutagenic agents 5-bromo-deoxyuridine and dimethyl sulphoxide has also resulted in a marked increase of cylindrical type C virus forms [28]. Because of the morphological characteristics and infrequent appearance of these virus forms, it has been suggested that cylindrical type $\mathrm{C}$ particles result from abnormalities in virus assembly in which elongation is associated with a failure to complete the budding process. Since streptozotocin has been demonstrated to have both oncogenic [29] and mutagenic [30] capabilities, it is possible that streptozotocin may interfere with the biochemical events associated with virus assembly and maturation. The absence of budding from beta cell plasma membranes and the limited tissue distribution of the type $\mathrm{C}$ viruses may indicate that the cylindrical particles represent immature non-infective forms.

The significance of intracisternal type $\mathrm{C}$ particles observed within the islet beta cells also remains enigmatic. Intracisternal type A particles have been 

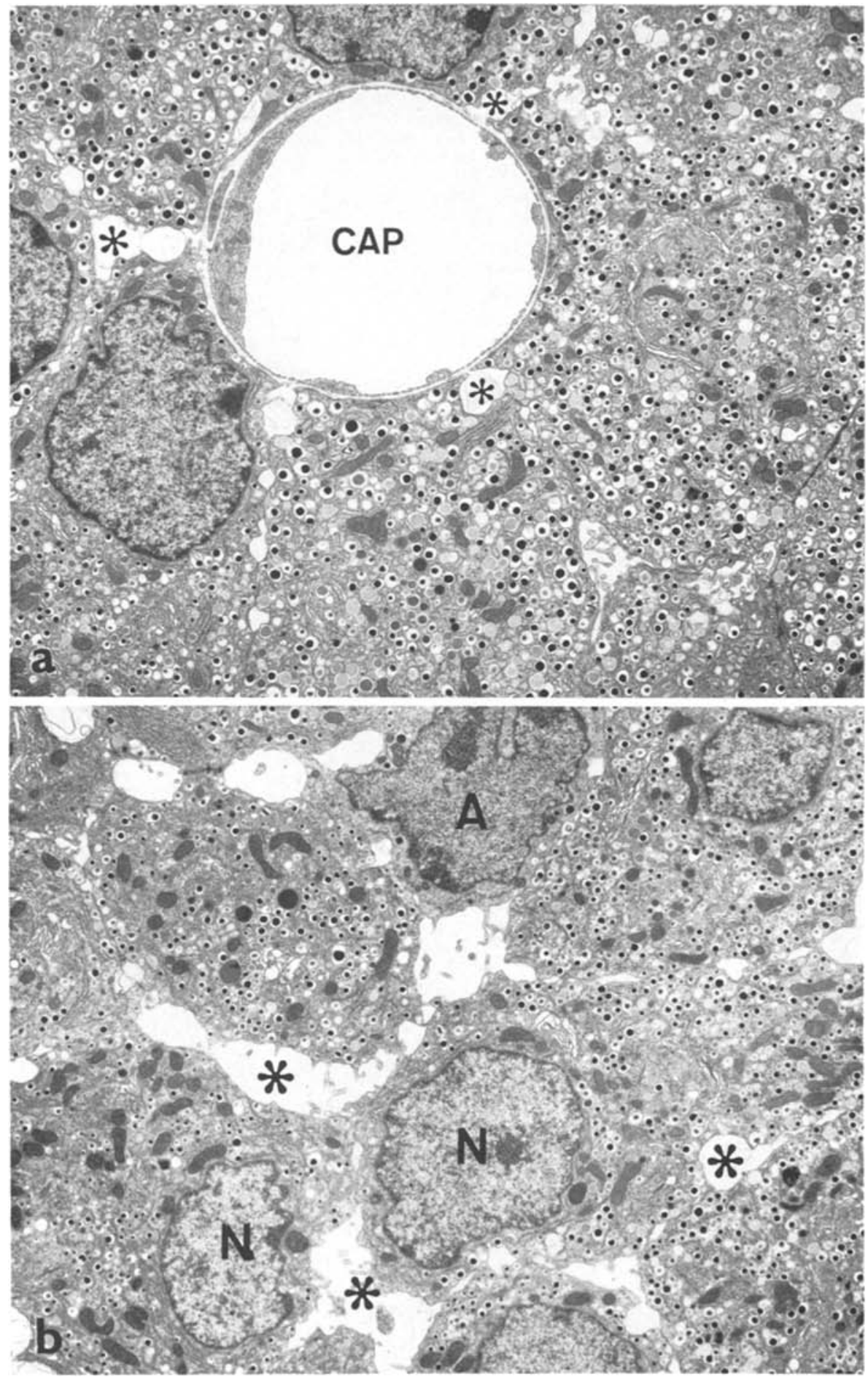

Fig. 4. a Electron micrograph from buffer injected CD-1 mouse. Beta cells are fully granulated. Minimal interstitial space $(*)$ separates opposing beta cells and an adjacent capillary (CAP). 4,100 $\times$ magnification. b Islet from CD-1 mouse sacrificed after completion of five stren- 

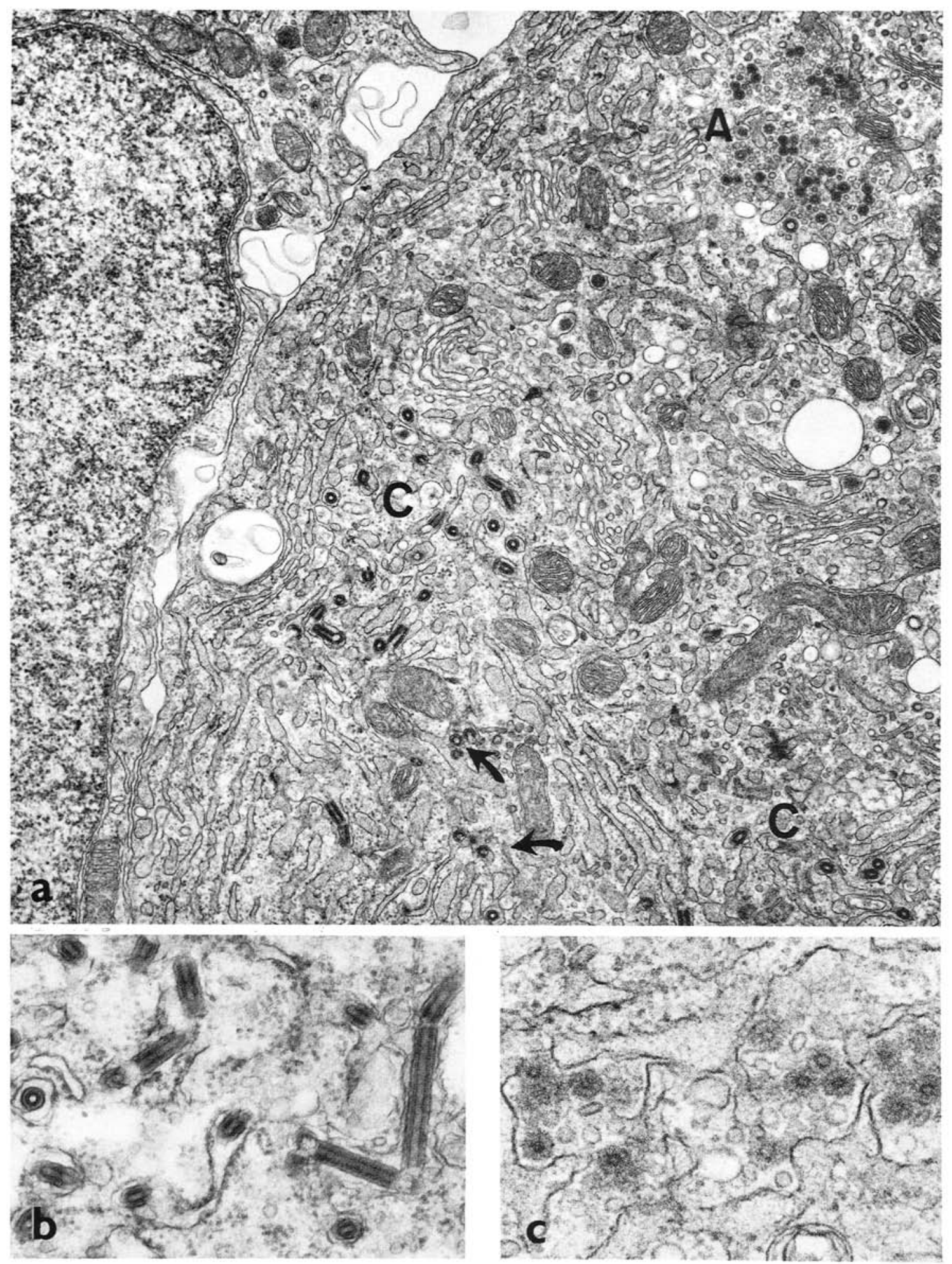

Fig. 5. a Beta cell from CD-1 mouse sacrificed on the eleventh day after receiving the first of five streptozotocin injections. Increased quantities of rough endoplasmic reticulum and beta degranulation are prominent. Clusters of type C (C) and intracisternal type A (A) particles are present. Arrows indicate sites of virus budding from cisternae of rough endoplasmic reticulum. $23,000 \times$ magnification. b High magnification electron micrograph illustrating substructure of cylindrical and spherical type $\mathrm{C}$ viruses. 65,000 magnification. $\mathrm{cHigh}$ magnification electron micrograph illustrating intracisternal type A virus particles. Surface projections ("spikes") extending from the nucleoid core are prominent. $70,000 \times$ magnification 


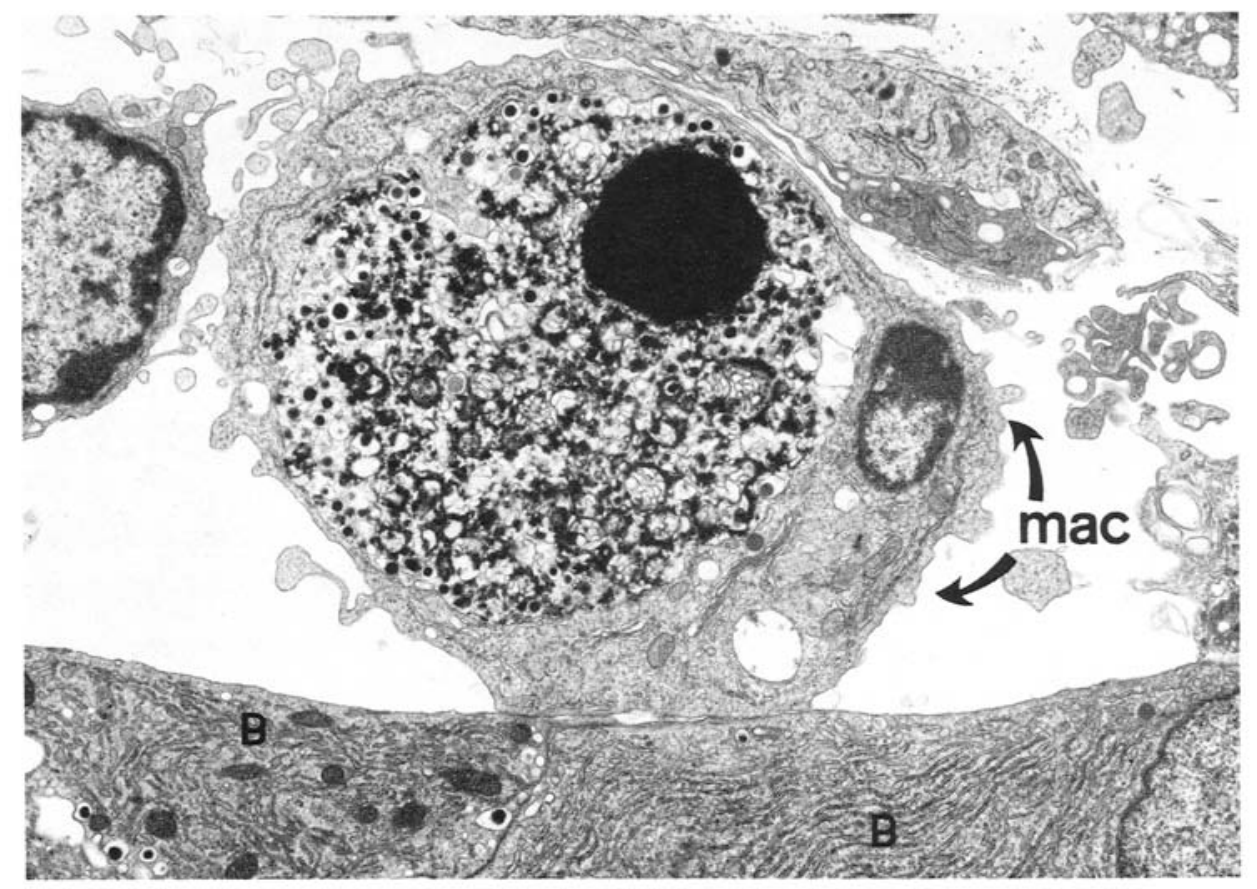

Fig. 6. Macrophage (MAC) containing phagocytised beta cell debris. $\mathrm{B}=$ beta cell. $6,000 \times$ magnification

occuring in CD-1 mice receiving multiple subdiabetogenic doses of streptozotocin contrasted sharply with the conventional events observed after a single large dose is used. When streptozotocin is administered as a single large dose, beta cells undergo necrosis within a twenty-four hour period and islets do not develop an inflammatory reaction. Due to the immediate toxic effect of streptozotocin upon the beta cells, islets rapidly become depleted of beta cells and a sustained hyperglycaemia is manifest within forty-eight hours after the injection [34]. Beta cells from CD-1 mice showed minimal ultrastructural abnormalities upon completion of five subdiabetogenic streptozotocin injections and developed necrosis only during the period of insulitis. Similarly, hyperglycaemia and hypoinsulinaemia were delayed and progressive. The above observations suggest that streptozotocin produces two distinct forms of diabetes in CD-1 mice when different dose schedules are used. Following a single large injection, diabetes results from the rapid irreversible beta cytotoxic effect of streptozotocin. After multiple small injections of streptozotocin, diabetes appears to result from a delayed cell-mediated immune attack directed against islet beta cells. Whether this delayed effect is due to structural alterations of beta cells, type $C$ virus induction, direct immune system interaction, or a combination of these three effects, remains to be determined.

Numerous reports have indicated that the type $C$ virus envelope protein, $\mathrm{gp} 70$, and the precursor polyprotein of the viral core structural proteins, are constituents of leukaemia cell membranes and are capable of serving as target hosts for an immune response $[35,36]$. Therefore, it is tempting to postulate that streptozotocin enhanced type $C$ virus induction results in structural changes of beta cell membranes which initiate a cell-mediated immune response. Using the methods described, the data suggest that viral induction preceded the arrival of the inflammatory cells by two days. If $\mathrm{CD}-1$ mice are naturally immune to endogenous type $C$ viral antigens, then the timing of these events is consistent with the possibility that virus related alterations of beta cells elicited a delayed hypersensitivity reaction within the islets. It is also conceivable that viral proteins are synthesised and localised as surface antigens on beta cell membranes days before viral assembly is completed. Additional studies utilising immunoelectron microscopy might help to establish the precise period of viral protein synthesis.

The mechanism by which streptozotocin enhances type $\mathrm{C}$ virus induction and produces insulitis remains unclear. Murine leukaemia viruses have also been experimentally induced by $\mathrm{X}$-irradiation [23] and numerous chemical agents including halogenated pyrimidines, steroids and nitrosoamines $[21,37,38]$. Presumably the sequence of events involves derepression of viral genetic information incorporated into the host genome (by mutation) or 
involves more subtle mechanisms of reversible alteration of regulator genes or gene products. However, both the capacity of the animal to express type C virus and the sensitivity of the host animal to viral antigens appear to be regulated by complex genetic factors [21, 39]. Evidence of an inherited susceptibility to streptozotocin-induced insulitis was supported by other studies in which eight strains of mice were given multiple streptozotocin injections and examined for the presence of insulitis [40]. Of the eight strains investigated only $\mathrm{C} 57 \mathrm{Bl} / \mathrm{KsJ}$ mice demonstrated an insulitis-diabetes syndrome comparable with CD-1 mice. Insulitis from these inbred C57B1/KsJ mice was also accompanied by increased replication of intracisternal A but not $C$ type virus particles (unpublished data). Further studies are necessary with each of these animal models to clarify the roles of streptozotocin and the viruses in the pathogenesis of pancreatic insulitis and to determine the predisposing hereditary factors.

Acknowledgements. Supported in part by research grants AM 19155, AM 15191, AM 05077, AM 21111, and CA 19791 from the U.S. Public Health Service, grants from the Juvenile Diabetes Foundation, the American Diabetes Association, the American Cancer Society, ACS IM-149 and the Upjohn Company. Michael C. Appel is a recipient of a postdoctoral research fellowship from the Juvenile Diabetes Foundation.

We wish to gratefully acknowledge the expert technical assistance of Ms. Claudia Berger, Serena Davis, Paula Erlandson and Deborah Schmidt. We appreciate, also, the expert photographic assistance of Mr. Peter Healey.

\section{References}

1. Solomon, N., Carpenter, C. J. C., Bennet, I. L., Harvey A. M.: Schmidt's syndrome (thyroid and adrenal insufficiency) and coexistant diabetes mellitus. Diabetes 14, 300-304 (1965)

2. Maccuish, A. C., Irvine, W. J.: Autoimmunological aspects of diabetes mellitus. Clin. Endocrinol. Metabol. 4, 435-471 (1975)

3. Volpe, R.: The role of autoimmunity in hypoendocrine and hyperendocrine function. Ann. Intern. Med. 87, 86-99 (1977)

4. Nerup, J., Binder, C.: Thyroid, gastric and adrenal autoimmunity in diabetes mellitus. Acta. Endocrinol. (Kbh.) 72, 279-286 (1973)

5. Nerup, J.: The clinical and immunological association of diabetes mellitus and Addison's disease. In: P. A. Bastenie, W. Gepts (eds.): Immunity and Autoimmunity in Diabetes Mellitus, p. 149-172. Amsterdam: Excerpta Medica 1974

6. Munichoodappa, C., Kozak, G.P.: Diabetes mellitus and pernicious anemia. Diabetes 19, 719-723 (1970)

7. Irvine, W. J., Clark, B. F., Scarth, L., Cullen, D. R., Duncan, L. J. P.: Thyroid and gastric autoimmunity in patients with diabetes mellitus. Lancet 1970 II, 163-168

8. Freytag, G., Kloppel, G.: Insulitis - a morphological review. Curr. Top. Pathol. 58, 49-90 (1972)

9. Botazzo, G. F., Florin-Christensen, A., Doniach, A.: Islet cell antibodies in diabetes mellitus with autoimmune polyendocrine deficiencies. Lancet 1974 II, 1279-1283

10. Sorenson, R. L., Shank, R. D., Elde, R. P.: Immunoperoxidase demonstration of human serum globulin binding to islet tissue. Diabetes 24, 230-237 (1975)
11. Gamble, D. R., Kinsley, M. L., Fitzgerald, M. G., Bolton, R., Taylor, K. W.: Viral antibodies in diabetes mellitus. Br. Med. J. 1969 III, 627-630

12. Forrest, J. M., Menser, M. A., Burgess, J. A.: High frequency of diabetes mellitus in young adults with congenital rubella. Lancet 1971 II, 332-334

13. Craighead, J.E.: The role of viruses in the pathogenesis of pancreatic disease and diabetes mellitus. Prog. Med. Virol. 19, 161-214 (1964)

14. Craighead, J. E., McLane, M. F.: Diabetes mellitus: Induction in mice by encephalomyocarditis virus. Science 162, 913-914 (1968)

15. Like, A. A., Rossini, A. A.: Streptozotocin-induced pancreatic insulitis; new model of diabetes mellitus. Science 193, 415-418 (1976)

16. Rossini, A. A., Like, A. A., Chick, W. L., Appel, M. C., Cahill, G. F., Jr.: Studies of streptozotocin induced insulitis and diabetes. Proc. Natl. Acad. Sci. USA 74, 2485-2489 (1977)

17. Like, A. A., Appel, M. C., Williams, R. M., Rossini, A. A.: Streptozotocin induced pancreatic insulitis in mice: Morphologic and physiologic studies. Lab. Invest. 38, 470-486 (1978)

18. Rossini, A. A., Berger, M., Shadden, J., Cahill, G. F., Jr.: Beta cell protection to alloxan necrosis by anomers of D-glucose. Science 183, 424-426 (1974)

19. Desbuquois, B., Aurbach, G. D.: Use of polyethylene glycol to separate free and antibody-bound peptide hormones in radioimmunoassays. J. Clin. Endocrinol. Metab. 33, 732-738 (1971)

20. Venable, J., Coggeshall, R.: A simplified lead citrate stain for use in electron microscopy. J. Cell Biol. 25, 407-408 (1965)

21. Yoshiki, T., Mellors, R.C., Hardy, W. D., Jr., Fleissner, E.: Common cell surface antigen associated with mammalian Ctype viruses. J. Exp. Med. 139, 925-942 (1974)

22. Feldman, D. G., Dreyfuss, Y., Gross, L.: Electron microscopic study of the mouse leukemia virus (gross) in organs of mouse embryos from virus-injected and normal C3HF parents. Cancer Res. 27, 1792-1804 (1967)

23. Aaronson, S. A., Stephenson, J. R.: Endogenous type-C RNA viruses of mammalian cells. Biochim. Biophys. Acta 458, 323-354 (1976)

24. Dalton, A. J., Hagnenau, F., Moloney, J. B.: Further electron microscopic studies on the morphology of the Moloney agent. J. Natl. Cancer Inst. 33, 255-275 (1964)

25. Yumoto, T., Recher, L., Sykes, J. A., Dmochowski, L.: Morphology and development of some murine leukemia viruses. Natl. Cancer Inst. Monogr. 22, 107-138 (1966)

26. Savage, N., Hackett, A.: Aberrant type $C$ virus production in a cell line derived from BALB/3T3. In: C. J. Arceneaux (ed.): Proceedings of the Thirtieth Annual Meeting, Electron Microscope Society of America, p. 286-287. Baton Rouge: Claitors Publishing Division 1972

27. Fujinaga, S., Poel, W., Williams, W. C., Dmochowski, L.: Biological and morphological studies of SJL/J strain reticulum cell neoplasms induced and transmitted serially in lowleukemia strain mice. Cancer Res. 30, 729-742 (1970)

28. Orenstein, J.M., Weinstein, I. B.: Filamentous forms of enveloped A particles in cell cultures from chemically induced rat hepatomas. Cancer Res. 33, 1998-2004 (1973)

29. Arison, R. N., Feudale, E. L.: Induction of renal tumor by streptozotocin in rats. Nature 214, 1254-1255 (1967)

30. Zimmer, D. M., Bhuyan, B. K.: Mutagenicity of streptozotocin and several other nitrosourea compounds in salmonella typhimurium. Mut. Res. 40, 218-288 (1976)

31. Wivel, N. A., Smith, G. H.: Distribution of intracisternal A particles in a variety of normal and neoplastic mouse tissues. Int. J. Cancer 7, 167-175 (1971) 
32. Calarco, P. G., Szollosi, D.: Intracisternal A particles in ova and preimplantation stages of the mouse. Nature 243, 91-93 (1973)

33. Hall, W. T., Hartley, J. W., Sanford, K. K.: Characteristics and relationship between $\mathrm{C}$ particles and intracisternal $\mathrm{A}$ particles in clonal strains. J. Virol. 2, 238-247 (1968)

34. Junod, A., Lambert, A. E., Stauffacher, W., Renold, A. E.: Diabetogenic action of streptozotocin: Relationship of dose to metabolic response. J. Clin. Invest. 48, 2129-2137 (1969)

35. Cantanzaro, P. J., Brandt, W. E., Hogrefe, W. R., Phillips, S. M., Top, F. H.: Virus enhanced modulation of cell surface antigens: Effect on immune lytic susceptibility. J. Immunol. 117, 1104-1110 (1976)

36. Ledbetter, J., Nowinski, R. C., Emery, S.: Viral proteins expressed on the surface of murine leukemia cells. J. Virol. 22, 65-73 (1977)

37. Hirsch, M. S., Black, P.H.: Activation of mammalian leukemia viruses. Adv. Virus Res. 19, 265-313 (1974).

38. Lowy, D. R., Rowe, W.P., Teich, N., Hartley, J. S.: Murine leukemia virus. High frequency activation in vitro by 5 iododeoxyuridine and 5-bromodeoxyuridine. Science 174, 155-156 (1971)

39. Gallo, R. C., Todaro, G. J.: Oncogenic RNA viruses. Semin. Oncol. 3, 81-95 (1976)

40. Rossini, A. A., Appel, M. C., Williams, R. M., Like, A. A.: Genetic influence of the streptozotocin-induced insulitis and hyperglycemia. Diabetes 26, 916-920 (1977)

Received: February 21, 1978,

and in revised form: May 22, 1978

Michael C. Appel, Ph. D.

Department of Pathology

University of Massachusetts Medical School

55 Lake Avenue, North

Worcester, MA 01605

USA 